\title{
GIS-Based Area Suitability Analysis for Development Planning Purposes Campus: Case Study Banyuwangi State Polytechnic
}

\author{
Endi Sailul Haq ${ }^{1}$ and Farisqi Panduardi ${ }^{2}$
}

\author{
1,2 Banyuwangi State Polytechnic, Jl. Raya Jember KM 13 Labanasem, Kabat, Banyuwangi 68461, Indonesia \\ ${ }^{I}$ Email: endi@poliwangi.ac.id
}

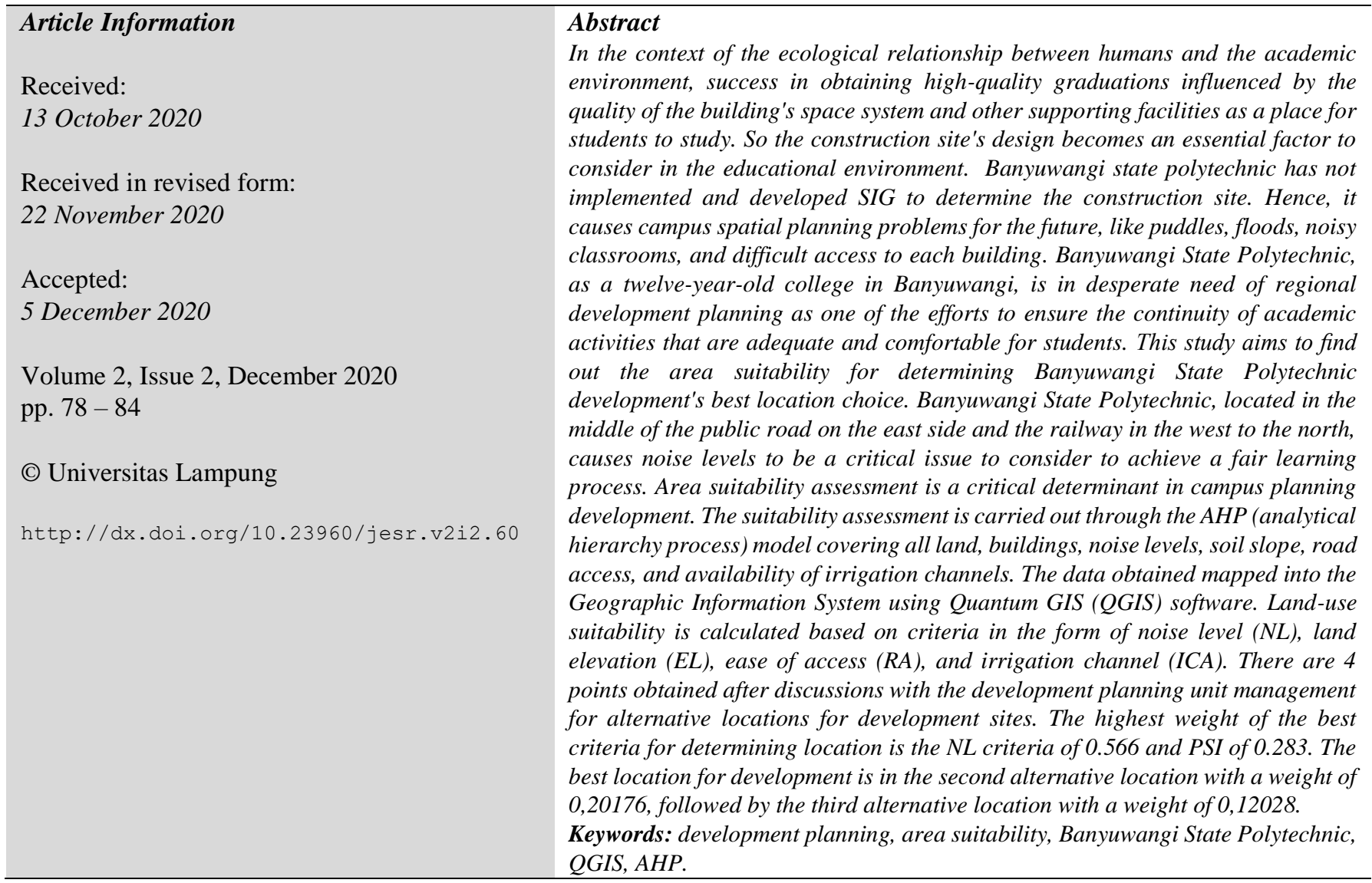

\section{INTRODUCTION}

B anyuwangi State Polytechnic College is an institution that continues to develop to ensure the sustainability of academic activities were adequate and comfortable for organizing the learning process. Therefore Banyuwangi State Polytechnic must always be ready to serve students, which is increasing every year. Geographic information systems are generally defined as a computer-based system that can manage, manipulate, and analyze geographic data or information. GIS has a strategic role because it can present the spatial aspects of the facts studied[1]. Good planning and management for educational institutions are absolutely necessary. Knowing characteristics and spatial information to achieve the best result is an essential step in making the right decision and planning[2].

For this reason, adequate information is needed to represent or model geographical data, including spatial information and spatial databases, especially to maximizing land functions and area information needs in terms of quantity and quality. The unavailability of information can have fatal consequences for programs and spatial planning projects of an educational institution. Correcting deficiencies in the use and management of information should be a top priority for collecting and processing relevant data because the data that are relevant for the planning and management of 
spatial educational institutions refer to spatial distribution. Geographic Information System (GIS) is the right technology to carry out inventory and monitoring in the management of areas that are supported by spatial databases. Previous research has carried out several methods to analyze the suitability of land use for various purposes, including using the fuzzy GIS method by applying the variables that influence it from satellite images to determine suitable land for housing[3], [4].

The Weighted Overlay Analysis method used for agricultural irrigation channels by calculating the weights on each dataset and combining them to find out a suitable location for agricultural land [5]. Spatial Multi-Criteria Decision Making Analysis (SMCDA) is also applied by assigning weight to criteria and ranking them to analyze impacts and urban planning with several practical approaches in decision making during planning [6]. AHP (Analytical Hierarchy Process), fuzzy evaluation, and genetic algorithms are combined to evaluate the urban settlement environment using multi-source data variables [7]

The mapping method using AHP (Analytical Hierarchy Process) has been widely applied and can translate unstructured data into hierarchical order. Giving values about how important variables are relative to setting more critical variables than other variables[8]-[10].

The AHP method is also useful in determining higher education development planning for both learning and other means[6], [11], [12]. Banyuwangi State Polytechnic has not applied GIS for the data collection process of buildings or land. So, this raises the difficulty in mapping the presentation of spatial planning. Therefore, the solution is to build an application by implementing GIS technology integrated with the database so that it is expected to provide convenience and help present the mapping of the Banyuwangi State Polytechnic region spatial data collection appropriately and adequately. Thus, this allows building data and the location of buildings or land to be visualized into a digital map information unit. It has about $10 \%$ area that has been developed and will carry out greater development in the future.

This study aims to find out the area suitability for determining Banyuwangi State Polytechnic development's best location choice. Banyuwangi State Polytechnic, located in the middle of the public road on the east side and the railway in the west to the north, causes noise levels to be a critical issue to consider to achieve a fair learning process.

\section{Materials AND MethodS}

The study area in Banyuwangi State Polytechnic spread over an area of 104.092 M2 refer to Fig. 1, and only $9 \%$ has been used for building. From the available land, Banyuwangi State Polytechnic plans to develop to become a quality educational institution and contribute to the advancement of the Banyuwangi region and the Republic of Indonesia.

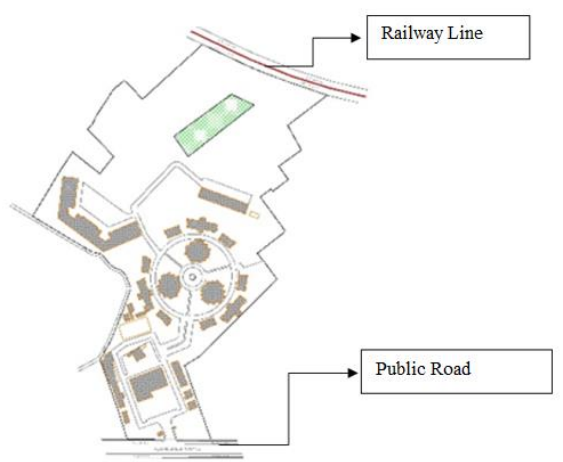

Figure 1. Banyuwangi State Polytechnic area

Location selection is a very decisive factor for the development of Banyuwangi State Polytechnic in the future. The arrangement concerning the condition of the land and its direction will have a profound effect on the success of the development itself. Based on the results of interviews and surveys, several factors determine the selection of development sites in Banyuwangi State Polytechnic. So careful consideration is needed so that the development can be targeted and under expectations. Factors that influence the selection of locations in Banyuwangi State Polytechnic based on previous analysis are determined as follows:

\section{A. Noise Level (NL)}

Considering that Banyuwangi State Polytechnic area (Figure 1) is in the middle of the public road on the east side and the railway line in the west to the north causes noise levels to be an important issue to consider in order to achieve a good learning process.

In addition, based on previous analysis of the source of noise, the arrangement of parking spaces that are too close to laboratories and classes is also caused. So from this situation, at certain times, the noise is very disruptive to the lecture process.

\section{B. Elevation (EL)}

Land elevation in Banyuwangi State Polytechnic (Figure 2) has a significant difference value. So it needs to be considered because land elevation will have a significant effect on flooding and inundation during the rainy season.

Based on area elevation measurements and mapping into the map, the south and east sides are relatively higher compared to other areas, whereas. If it rains, water flows from the west side and will echo around the informatics engineering program building on the medial side. 


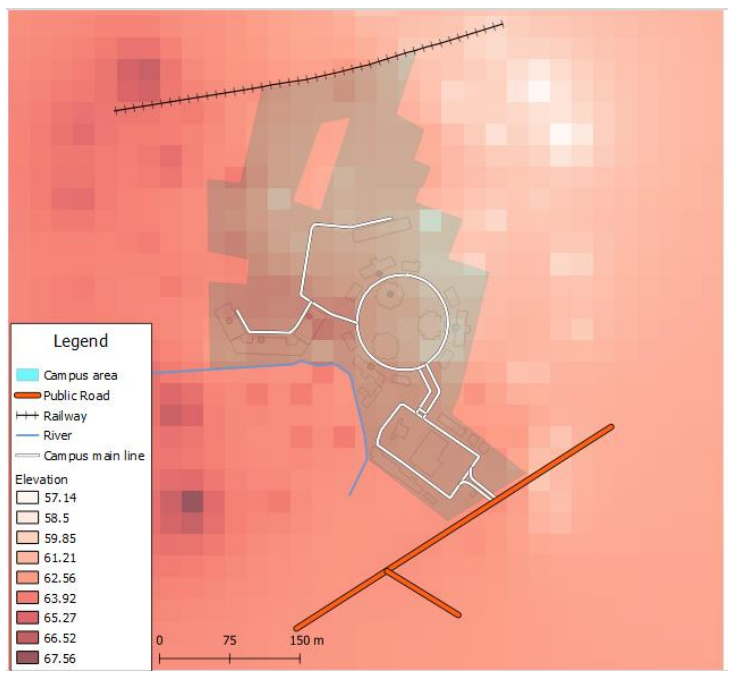

Figure 2. Banyuwangi State Polytechnic Elevation

\section{Access Readiness $(A R)$}

The ease of access to the new building's location is necessary, given the Banyuwangi State Polytechnic area extending from the east and then widening on the west and north sides (Figure 3). Given the JINGGO hotel's existence in the southwest and the main access road to reach it, have to pass through the existing lecture building. Of course, this will significantly interfere with learning activities and comfort

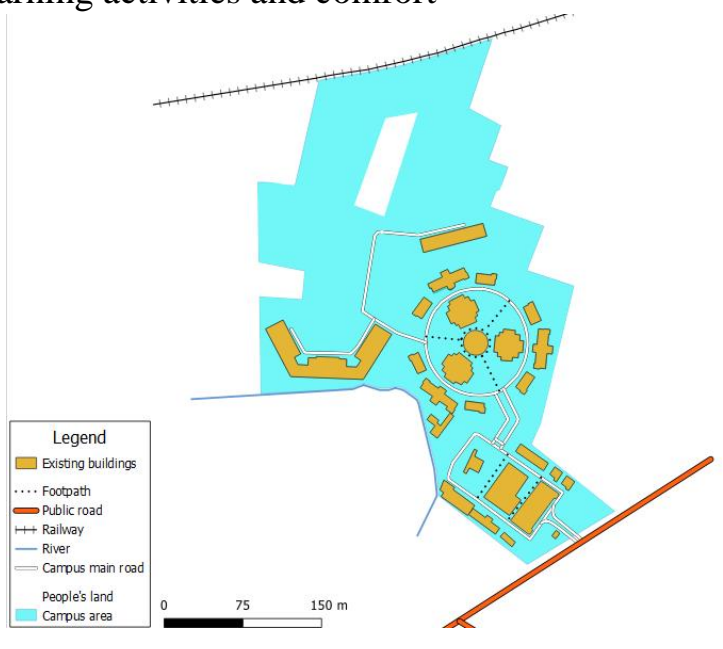

Figure 3 Existing Access

\section{Irrigation Channel Avaibility (ICA)}

Irrigation channels certainly need to be considered not to cause inundation and reduce the potential for flooding during the rainy season. Based on area elevation measurements and mapping into the map of irrigation channels in Banyuwangi State Polytechnic is still not well organized (Figure 4).

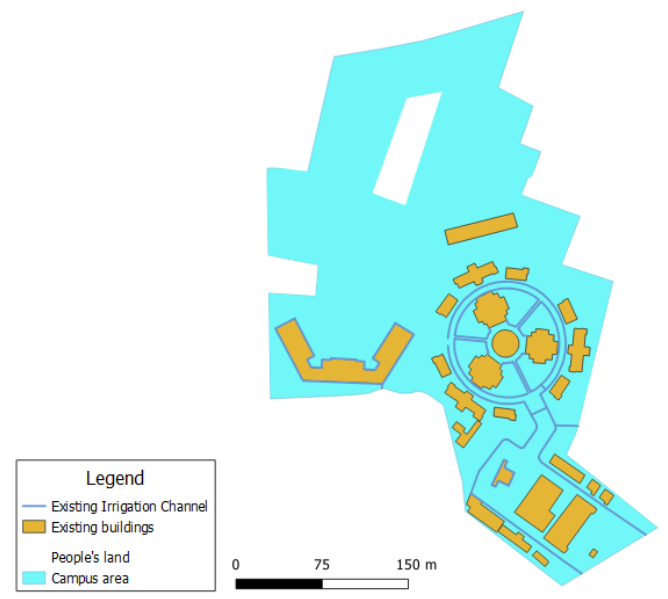

Figure 4 Existing Irrigation Channel

After defining the problem, the next step is to determine the problem as a criterion in determining the location of development at the Banyuwangi State Polytechnic using the AHP (Analytical Hierarchy Process) method. Before the calculation process is carried out, the assessment scale (Table 1) is first determined for each criterion.

Table 1. Criterions Assesment

\begin{tabular}{c|c|l}
\hline No & Value & \multicolumn{1}{|c}{ Criterions Scale } \\
\hline $\mathbf{1}$ & & Noise Level (NL) \\
\hline & 9 & Low noise level \\
\hline & 7 & Current noise level \\
\hline & 5 & Sound level is quite high \\
\hline & 1 & High noise level \\
\hline $\mathbf{2}$ & $2,4,6,8$ & When the level of noise is doubted \\
\hline & 9 & Elevation (EL) \\
\hline & 7 & moderate slope level \\
\hline & 5 & the slope level is rather large \\
\hline & 3 & large slope level \\
\hline & 1 & huge slope level \\
\hline & $2,4,6,8$ & When the distance doubted the level of slope \\
\hline $\mathbf{3}$ & & Access Readiness (AR) \\
\hline & 9 & near the main access point \\
\hline & 7 & a bit close to the main access point \\
\hline & 5 & a bit far with the main access point \\
\hline & 3 & with the main access point \\
\hline & 1 & very far with the main access point \\
\hline & & When the distance doubted with the main \\
\hline & & Irrigation Channel Avaibility (ICA) \\
\hline & & \\
\hline & &
\end{tabular}




\begin{tabular}{c|c|l}
\hline & 9 & very close to irrigation channels \\
\hline & 7 & pretty close to the irrigation channel \\
\hline & 5 & a little far from the irrigation channel \\
\hline & 1 & away with irrigation channels \\
\hline & $2,4,6,8$ & $\begin{array}{l}\text { When the distance doubted with the } \\
\text { irrigation channel }\end{array}$ \\
\hline
\end{tabular}

The next steps create a hierarchy structure (Figure 5) that begins by determining the main objective, followed by determining the criteria and the possibility of alternatives at the very bottom level. From the structure of the hierarchy below, it can be known that the first level is the main level of purpose that is to find the best location of development in Banyuwangi State Polytechnic. The second level is the criteria for achieving the primary goal. While the third level is an alternative, it is filled with several alternative locations for development sites.

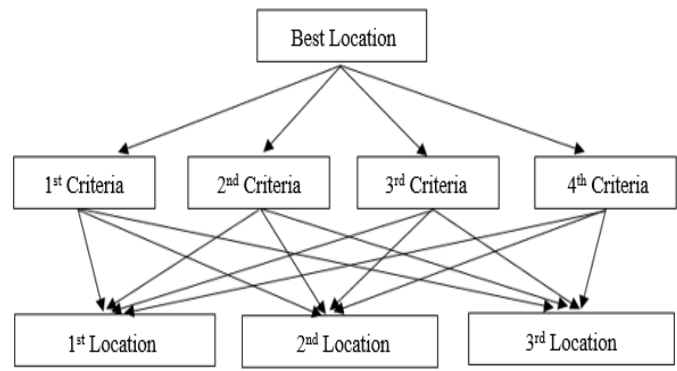

Figure 5 Hierarchy of Goals

The next step is continued by making a comparison matrix table of the specified criteria and alternative locations (Table 2). The comparison matrix table reflects the priority or dominance of one criterion to another by providing a quantitative scale of 1 to 9 [13].

Table 2. Comparison Matrix

\begin{tabular}{c|c|c|c|c}
\hline Criterion & $\mathrm{C} 1$ & $\mathrm{C} 2$ & $\ldots$. & $\mathrm{Cj}$ \\
\hline $\mathrm{C} 1$ & $\mathrm{C} 1 / \mathrm{C} 1$ & $\mathrm{C} 1 / \mathrm{C} 2$ & $\ldots .$. & $\mathrm{C} 1 / \mathrm{Cj}$ \\
\hline $\mathrm{C} 2$ & $\mathrm{C} 2 / \mathrm{C} 1$ & $\mathrm{C} 2 / \mathrm{C} 2$ & & $\mathrm{C} 1 / \mathrm{Cj}$ \\
\hline & & & & \\
$\vdots$ & $\vdots$ & $\vdots$ & $\vdots$ & $\vdots$ \\
& & & & $\vdots$ \\
\hline $\mathrm{Ci}$ & $\mathrm{Ci} / \mathrm{C} 1$ & $\mathrm{Ci} / \mathrm{C} 2$ & $\ldots .$. & $\mathrm{Ci} / \mathrm{Cj}$ \\
\hline
\end{tabular}

Comparison value in pairs between $\mathrm{Ci}$ and $\mathrm{Cj}$ is matrix $\mathrm{C}$, whose elements are $\mathrm{Cij}$.

$$
\mathrm{C}_{\mathrm{i}} / \mathrm{C}_{\mathrm{j}}=\mathrm{C}_{\mathrm{ij}} ; \mathrm{i}, \mathrm{j}=1,2, \ldots \mathrm{n}
$$

The weight of each element $C_{i j}$ is a comparison of the ratings for each developed criterion. In the case study determining a suitable location for development at the
Banyuwangi State Polytechnic, four criteria serve as elements of comparison described in the hierarchical structure of the objectives. The calculation of the weight of each criterion obtained from the equation below:

$$
\begin{gathered}
M_{n}=\left(C_{n a} \times C_{n b} \times C_{n c} \times \ldots C_{n n}\right)^{1 / n} \\
P_{n}=\frac{M_{n}}{\sum M}
\end{gathered}
$$

Where:

$\mathrm{n}$ : number of columns

$\mathrm{C}$ : matrix elements

M : temporary matrix weight

$\mathrm{P} \quad$ : Priority weight

Errors in the matrix coefficient will cause deviations in the eigenvalue. Deviation from consistency expressed by the Consistency Index (CI). Where Eigenvalue ( $(\lambda M a x)$ was obtained by summing the multiplication between the number of comparation values on each element's row with the number of weights in each column.

$$
C I=\frac{\lambda M a x-n}{n-1}
$$

CI value is used to calculate the value of the consistency ratio (CR) by comparing the CI value with the index ratio value (RI). From the size of the criteria matrix above, the RI value $=0.9$. Therefore, $\mathrm{CR}$ can be calculated using equations below

$$
C R=\frac{C I}{R I}
$$

\section{RESUltS AND DiscusSiONS}

According to the steps in the previous chapter, to determine the best location for development at the Banyuwangi State Polytechnic using the AHP method. Creating a comparison matrix for each criterion is in consultation with the campus development planning unit. The comparison matrix produced using equation (1) is shown in the Table 3 below:

Table 3 Criterion Comparison Matrix

\begin{tabular}{c|c|c|c|c}
\hline & EL & NL & AR & ICA \\
\hline EL & 1,0000 & 0,2000 & 2,0000 & 0,3333 \\
\hline NL & 5,0000 & 1,0000 & 4,0000 & 2,0000 \\
\hline AR & 0,5000 & 0,2500 & 1,0000 & 0,2000 \\
\hline ICA & 3,0000 & 0,5000 & 5,0000 & 1,0000 \\
\hline Sum & $\mathbf{9 , 5 0 0 0}$ & $\mathbf{1 , 9 5 0 0}$ & $\mathbf{1 2 , 0 0 0 0}$ & $\mathbf{3 , 5 3 3 3}$ \\
\hline
\end{tabular}

Calculation of the weight element for each criterion using equations (2) and (3) shows the results in the Table 4 below. 
Table 4 Weight Element

\begin{tabular}{l|l|l|l|r|r}
\hline Criterion & \multicolumn{4}{|c|}{ Weight Each Elemen } & Weights \\
\hline EL & 0,105 & 0,103 & 0,167 & 0,094 & 0,117 \\
\hline NL & 0,526 & 0,513 & 0,333 & 0,566 & 0,485 \\
\hline AR & 0,053 & 0,128 & 0,083 & 0,057 & 0,080 \\
\hline ICA & 0,316 & 0,256 & 0,417 & 0,283 & 0,318 \\
\hline
\end{tabular}

From the Table 4 above, it was known that the eigenvalue is 4,144 . So using equation (4), the $\mathrm{CI}$ value can be calculated as follows:

$$
\begin{aligned}
& C I=\frac{4,144-4}{4-1} \\
& C I=0,048
\end{aligned}
$$

The RI value that used is the random index value issued by the Oakridge Laboratory [13], Thus, the value of RI with four criteria is 0.90 . Finally, the CR value can be calculated using equation (5) and get a result of 0.053. Since the CR value is smaller than 0.1 , then the comparison criterion can be said to be consistent.

In order to determine a suitable location in the Banyuwangi State Polytechnic, alternative locations were selected. These locations are candidates for future development. Based on the survey results and interviews with the campus development planning unit, four alternative locations obtained, as shown in the picture below.

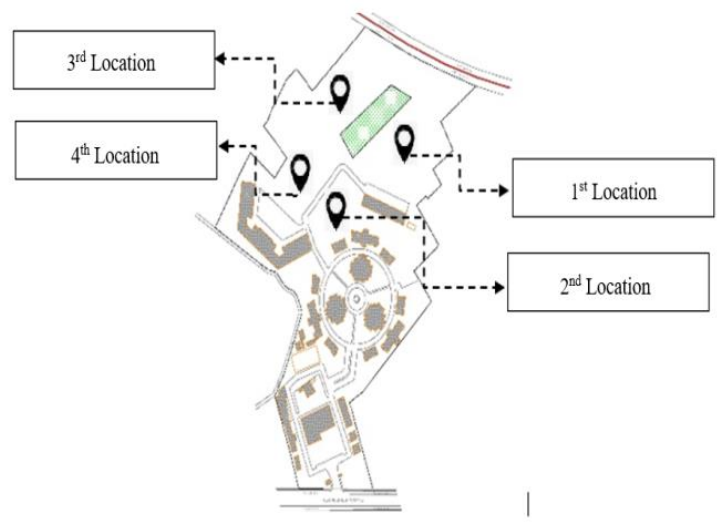

Figure 6 Alternative Location Points

Each of these alternate locations was processed by comparing alternatives based on the most significant criteria weight value in the (Table 4). Based on the calculation of the weight of the previous criteria obtained the most significant weight on the noise level (NL) criteria of 0.485 . Thus the alternative locations comparison calculated on NL only. So that a comparison table can be created as follows:

Table 5 Location Comparison based on NL Criteria

\begin{tabular}{c|c|c|c|c}
\hline & $\begin{array}{c}1^{\text {st }} \\
\text { Location }\end{array}$ & $\begin{array}{c}2^{\text {nd }} \\
\text { Location }\end{array}$ & $\begin{array}{c}3^{\text {rd }} \\
\text { Location }\end{array}$ & $\begin{array}{c}4^{\text {th }} \\
\text { Location }\end{array}$ \\
\hline $\begin{array}{c}1^{\text {st }} \\
\text { Location }\end{array}$ & 1,0000 & 0,2000 & 1,0000 & 0,2500 \\
\hline $\begin{array}{c}2^{\text {nd }} \\
\text { Location }\end{array}$ & 5,0000 & 1,0000 & 4,0000 & 1,0000 \\
\hline $\begin{array}{c}3^{\text {rd }} \\
\text { Location }\end{array}$ & 1,0000 & 0,2500 & 1,0000 & 4,0000 \\
\hline $\begin{array}{c}4^{\text {th }} \\
\text { Location }\end{array}$ & 4,0000 & 1,0000 & 0,2500 & 1,0000 \\
\hline Sum & 11,0000 & 2,4500 & 6,2500 & 6,2500 \\
\hline
\end{tabular}

By using equations (2) and (3) the weights shows in table below:

Table 6 Weight Elemen for Location based on NL Criteria

\begin{tabular}{l|c|r|r|r|r}
\hline Locations & \multicolumn{4}{|c|}{ Weight Each Elemen } & Weights \\
\hline $\begin{array}{l}1^{\text {st }} \\
\text { Location }\end{array}$ & 0,091 & 0,082 & 0,160 & 0,040 & 0,093 \\
\hline $2^{\text {nd }}$ & 0,455 & 0,408 & 0,640 & 0,160 & 0,416 \\
Location & & & & & \\
\hline $3^{\text {rd }}$ & 0,091 & 0,102 & 0,160 & 0,640 & 0,248 \\
Location & & & & & \\
\hline $\begin{array}{l}\text { th } \\
\text { Location }\end{array}$ & 0,364 & 0,408 & 0,040 & 0,160 & 0,243 \\
\hline
\end{tabular}

According to primary purpose determine the best location for development in the Banyuwangi State Polytechnic, the weight matrix at the alternative location multiplied by the weight matrix of the criteria (Table 6) and the value generated as shown below:

Table 7 Decision Result

\begin{tabular}{l|r|l|l|l}
\hline $\begin{array}{l}\text { Locations } \\
\text { Alternative }\end{array}$ & $\begin{array}{l}\text { Location } \\
\text { Weight }\end{array}$ & & $\begin{array}{l}\text { NL } \\
\text { Weight }\end{array}$ & \multicolumn{1}{|c}{ Result } \\
\cline { 1 - 2 } $1^{\text {st }}$ Location & 0,093 & \multirow{3}{*}{ X } & & 0,045105 \\
\hline $2^{\text {nd }}$ Location & 0,416 & & 0,485 & 0,20176 \\
\hline $3^{\text {rd }}$ Location & 0,248 & & & 0,12028 \\
\hline $4^{\text {th }}$ Location & 0,243 & & & 0,117855 \\
\hline
\end{tabular}

Based on the Table 7 above, it can be concluded that the best location for development at the Banyuwangi State Polytechnic from mapping using GIS and calculations using the AHP method sequentially located at alternative location point 2 , followed by alternative location point 3 , alternative location point 4 and alternative location point 1 .

Previously, related studies based on GIS analysis were conducted to get information for effective and efficient campus management [14]. In agreement with [6], [9], [12] education institution has a complex requirement, and many information is needed for future development and can be easily redesigned and predict how the campus should be. However, the weighting process should be highly objective and preferably involving consultants to help campus management quickly 
provide future development plans

\section{Conclusions}

Banyuwangi State Polytechnic, a twelve-year-old college in Banyuwangi, has not implemented and developed SIG to determine the construction site. This study aims to find out the area suitability for determining Banyuwangi State Polytechnic development's best location choice. Banyuwangi State Polytechnic, located in the middle of the public road on the east side and the railway in the west to the north, causes noise levels to be a critical issue to consider to achieve a fair learning process. Area suitability assessment is a critical determinant in campus planning development. The suitability assessment is carried out through the AHP (analytical hierarchy process) model covering all land, buildings, noise levels, soil slope, road access, and availability of irrigation channels.

There are 4 points obtained after discussions with the development planning unit management for alternative locations for development sites. The result shown land suitability evaluation using The Analytical Hierarchy Process (AHP) method can be applied and implemented for Decision Support in determining the priority development locations at the Banyuwangi State Polytechnic.

\section{ACKNOWLEDGMENT}

The authors would like to gratefully acknowledge the Polytechnic State of Banyuwangi for the support of the research.

\section{REFERENCES}

[1] H. Akincii, O. A. Y and B. Turgut,"Agricultural land use suitability analysis using GIS and AHP technique," Computers and Electronics in Agriculture, vol. 97, p. 71-82, 2013.

[2] S. M. Bukari, M. A. Ahmad, K. Wai T. L., M. and N. Alimin, "Spatial Analysis in Determination of Flood Prone Areas Using Geographic Information System and Analytical Hierarchy Process at Sungai Sembrong's Catchment," Materials Science and Engineering, vol. 136, no. 1, 2016.

[3] Çeker, A. Kılıç, Z. Belge and R. D. E., "Creating Campus Information Systems of Marmara University (MUKBIS) by Using Geographic Information Systems (GIS): A Case Study of Göztepe Campus," in
GEOMED 2016 4th International Geography Symposium, 2016.

[4] G. P. K, "Web-Gis Based Campus Information System for National Institute Web-Gis Based Campus Information System," 2016.

[5] K. H, W. G and B. S, "A GIS-Based MultiCriteria Land Suitability Analysis for Surface Irrigation along the Erer," East African Journal of Sciences Multi-Criteria Land Suitability Analysis for Surface Irrigation along the Erer, vol. 13, p. 169-184, 2019.

[6] L. J, D. P, S. A and F. L, "Evaluation on the natural suitability of urban human settlement environment using multisource data.," in Joint Urban Remote Sensing Event, JURSE, 2015.

[7] M. J, "GIS-based land-use suitability analysis: A critical overview," Progress in, vol. 62, no. 1, pp. 3-65, 2004.

[8] R. Qutieshat, "Using GIS in Universities Campus Design University of Jordan as a Case Study," vol. 6, no. 5, pp. 25-30, 2015.

[9] R. W. Saaty, "The analytic hierarchy processwhat it is and how it is used," Mathematical modeling, vol. 9, no. 3, p. 161-176, 1987.

[10] T. L. Saaty, "Time dependent decisionmaking; dynamic priorities in the AHP/ANP: Generalizing from points to functions and from real to complex variables.," Mathematical and Computer Modelling, vol. 46, no. 7, p. 860-891, 2007.

[11] S. M and S. P, "GIS-based Land Suitability Analysis to Support Transit-Oriented Development (TOD) Master Plan: A Case Study of the Campus Station of Thammasat University and Its," International Journal of Building, Urban, Interior and Landscape, vol. 9, p. 49-60, 2017.

[12] C. Tarhan, O. Saygin and A. K. Cinar, "A GisBased Campus Information System : Izmir Institute of Technology," Izmir Institute of Technology, 2009. 
[13] S. G. Yalew, A. V. Griensven and P. v. d. Zaag, "AgriSuit: A web-based GIS-MCDA framework for agricultural land suitability assessment," Computers and Electronics in Agriculture, vol. 128, pp. 1-8, 2016.
[14] C. F. Z. W. X Zhang and H. Ma, "Urban construction land suitability evaluation based on improved multi-criteria evaluation based on GIS (MCE-GIS): Case of New Hefei City, China.," Chinese Geographical Science, vol. 23, no. 6, p. 740-753, 2013. 